\title{
RECOMMENDATIONS ON CLINICAL PRACTICE
}

\section{Approaching oropharyngeal dysphagia}

\author{
P. Clavé ${ }^{1,2}$, R. Terré 1 M. de $\operatorname{Kraa}^{2}$ and M. Serra ${ }^{2}$ \\ ${ }^{1}$ Unit of Digestive Neurophisiology. Institut Guttmann. Badalona, Barcelona. ${ }^{2}$ Unit of Digestive Explorations. Hospital \\ de Mataró. Barcelona, Spain
}

\section{INTRODUCTION}

Dysphagia is a symptom that refers to difficulty or discomfort during the progression of the alimentary bolus from the mouth to the stomach. From an anatomical standpoint dysphagia may result from oropharyngeal or esophageal dysfunction and from other structure-related or functional causes from a pathophysiological viewpoint. The prevalence of oropharyngeal functional dysphagia is very high in patients with neurological disease: it includes more than $30 \%$ of patients having had a CVA; its prevalence in Parkinson's disease is $52-82 \%$; it is the first symptom for $60 \%$ of patients with amyotrophic lateral sclerosis (ALS); it affects $40 \%$ of patients with myasthenia gravis, up to $44 \%$ of patients with multiple sclerosis; up to $84 \%$ of patients with Alzheimer's disease, and more than $60 \%$ of elderly institutionalized patients (1-5). The severity of oropharyngeal dysphagia may vary from moderate difficulty to complete inability to swallow.

Oropharyngeal dysphagia may give rise to two groups of clinically relevant complications:

1 . When a decrease in deglutition efficacy occurs, patients present with malnutrition and/or dehydration.

2. When a decrease in deglutition safety occurs, choking and airway obstruction develop, most commonly as a tracheobronchial aspiration that may result in pneumonia in $50 \%$ of cases, with an associated mortality up to $50 \%(1)$.

Clavé $P$, Terré $R$, de Kraa M, Serra M. Approaching oropharyngeal dysphagia. Rev Esp Enferm Dig 2004; 96: 119-131.

Recibido: 14-09-03.

Aceptado: 23-09-03.

Correspondencia: Pere Clavé i Civit. Unidad de Exploraciones Funcionales Digestivas. Hospital de Mataró. Consorci Sanitari del Maresme. Ctra. de Cirera, s/n. 08304 Mataró. Barcelona. Tel.: 9374177 00. Fax: 9374177

33. e-mail:pclave@teleline.es

\section{OBJECTIVE}

To define a set of clinical recommendations aimed at facilitating the diagnosis and management of patients with functional oropharyngeal dysphagia.

\section{METHOD}

This review on the approach to functional oropharyngeal dysphagia is based on the discussion of recommendations issued within consensus papers relying on "best evidence and best medical practice" by the following groups of experts:

-AGA Technical Review on Management of Oropharyngeal Dysphagia (1).

—www.dysphagiaonline.com (2).

-Evidence Report/Technology Assessment. Agency for Health Care Policy and Research. USA (3).

-Interventions for dysphagia in acute stroke. Cochrane Review (4).

-Disfagia Neurógena: Evaluación y Tratamiento. Fundació Institut Guttmann. Hospital de Neurorrehabilitación (5).

\section{NORMAL DEGLUTITION}

Normal deglutition comprises four stages; any of these stages (commonly more than just one) may be affected and result in dysphagia:

1 . The oral preparatory stage is under voluntary control and is aimed at mastication and bolus formation.

2. The oral stage is also voluntary, and is characterized by bolus propulsion by the tongue.

3 . The pharyngeal stage is involuntary and is triggered by an activation of pharyngeal mechanoreceptors that send information to the CNS and trigger the so-called pharyngeal deglutition motor pattern (deglutition reflex), 
which is characterized by an orderly sequence of consistent motor events that result in closure of the nasopharynx (soft palate elevation) and the airway (hyoid bone elevation and anterior displacement, lowered epiglottis, and vocal cord closure), opening of the upper esophageal sphincter (UES), and contraction of pharyngeal constrictor muscles. The tongue is primarily responsible for bolus propulsion, and the main goal of pharyngeal constrictor muscles is the clearance of bolus remnants within the hypopharynx.

4. The esophageal stage begins with the opening of UES, which is followed by esophageal peristalsis.

\section{PATHOPHYSIOLOGY OF DYSPHAGIA}

Dysphagia may result from a wide range of structural alterations that may hinder or prevent oropharyngeal reconfiguration during deglutition from the airway to the alimentary canal, or hamper the bolus progression, and also functional alterations that may impair bolus propulsion of pharyngeal configuration. Most common structural abnormalities include esophageal and ENT tumors, neck osteophytes, commonly postsurgical esophageal stenosis, upper sphincter aperture disturbances (cricopharyngeal bar, cricopharyngeal achalasia), and Zenker's diverticulum. However, oropharyngeal dysphagia is frequently a clinical manifestation of a systemic or neurological disease, or associated with ageing. Most commonly dysphagia precedes other neurological symptoms (6). Neurological disease may also bring about impairment in the function of esophageal smooth and striated muscles, or of motor neurons at the myenteric plexus, which control esophageal width and peristalsis, and the relaxation of the lower esophageal sphincter. In addition, esophageal dysphagia may be a common symptom of gastroesophageal reflux disease, whose prevalence is also increased in a great number of patient subsets with neurogenic dysphagia.

\section{DIAGNOSIS OF DYSPHAGIA}

\section{Dysphagia multidisciplinary team. Dysphagia units}

The diagnosis and management of oropharyngeal dysphagia calls for a multidisciplinary approach. A $d y s-$ phagia multidisciplinary team should be knowledgeable of a number of professional spheres and include: nurses, language therapists, gastroenterologists, ENT specialists, neurologists, rehabilitation physicians, surgeons, dieticians, radiologists, geriatrists, etc. The operativeness example set by some of these teams has revealed the small relevance of their members' baseline training, and the great significance of skill development as a group to provide coverage for the spectrum of diagnostic and therapeutic needs of patients with dysphagia by meeting common criteria. The goals of a dysphagia multidiscipli- nary team include: a) the identification of patients with dysphagia; b) a diagnosis of any medical or surgical etiology for dysphagia that may respond to a specific treatment, the exclusion of ENT and esophageal tumors, and the identification of gastroesophageal reflux and its complications; c) a characterization of biomechanical oropharyngeal changes responsible for dyaphagia in individual patients; and d) the design of a set of therapeutic strategies to provide the patient with safe and effective deglutition, or the provision of an alternative route to oral feeding based on objective and reproducible data. Family involvement in the diagnostic and therapeutic process is of paramount importance. Diagnostic and therapeutic resources are commonly concentrated in the so-called dysphagia units or centers (swallowing centers), which serve as referral institutions where patients with oropharyngeal dysphagia from several hospitals may be offered all the diagnostic modalities and treatments or management approaches they need.

\section{A program for the diagnosis of oropharyngeal dysphagia}

The diagnostic algorithm shown in figure 1 summarizes the diagnostic strategy for patients with oropharyngeal dysphagia. Once structural causes have been ruled out (particularly ENT and esophageal tumors), and a diagnosis of functional oropharyngeal dysphagia has been established, the goal of the diagnostic program is to evaluate two deglutition-defining characteristics: a) efficacy, the patient's ability to ingest all the calories and water he or she needs to remain adequately nourished and hydrated; and b) safety, the patient's ability to ingest all needed calories and water with no respiratory complications. To assess both characteristics of deglutition two groups of diagnostic methods are available: a) clinical methods such as deglutition-specific medical history and clinical examination; and b) the exploration of deglutition using specific complementary studies such as pharyngoesophageal videofluoroscopy and manometry.

\section{Clinical methods: clinical history and examination for deglutition disorders}

The program for the diagnosis of oropharyngeal dysphagia starts with clinical methods (Fig. 1). Their objective is to determine whether symptoms correspond to oropharyngeal dysphagia, to decide whether the patient will require complementary studies, and to identify potential nutritional and respiratory complications. The examination should include an assessment of behavioral, cognitive, and language aspects, which are needed when evaluating dysphagia mechanisms and treatment possibilities, and any neurological focalities should be definitely ruled out. The two major clinical methods are a specific clini- 


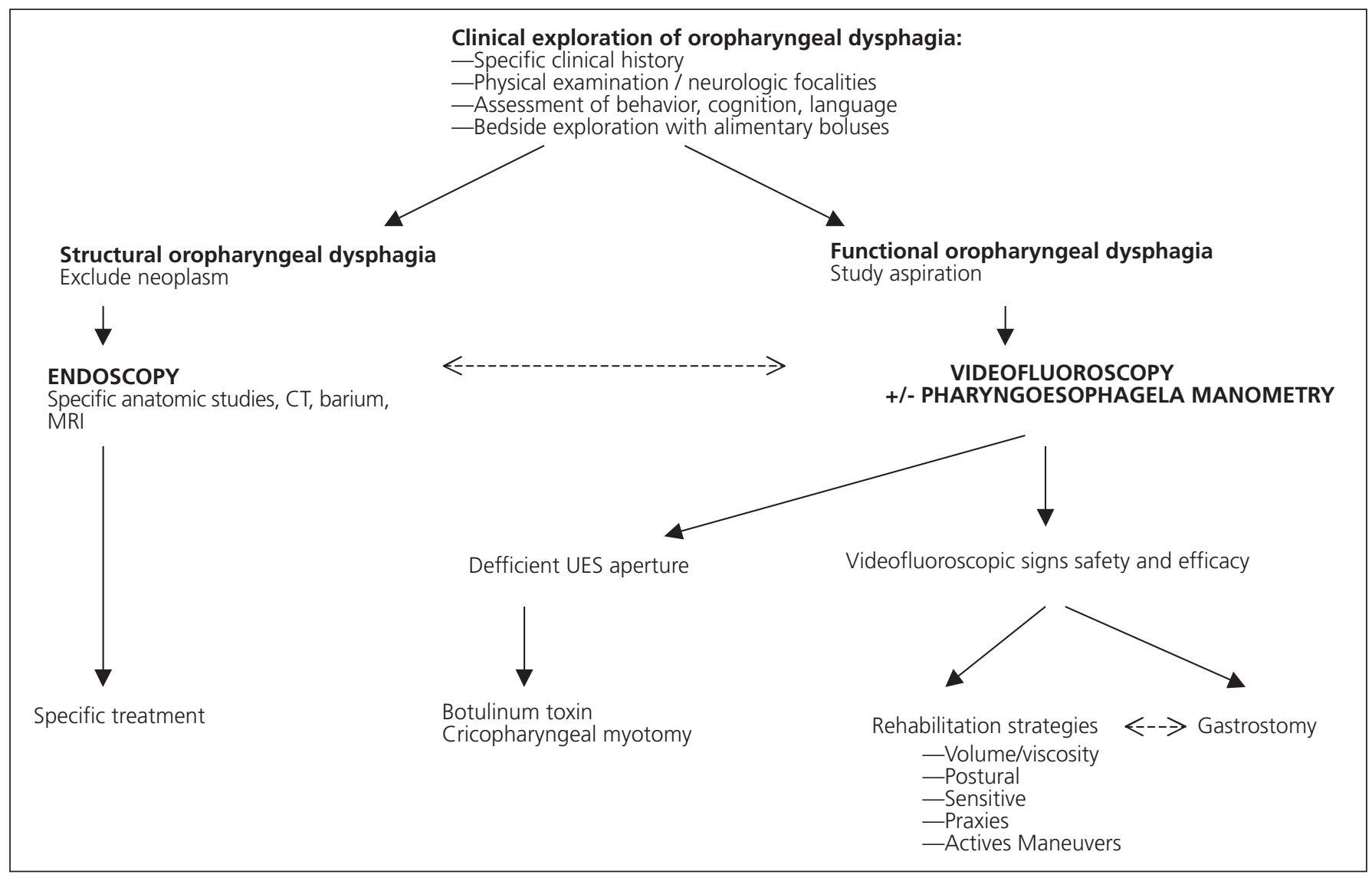

Fig. 1.- Diagnostic and therapeutic algorithm for patients with oropharyngeal dysphagia (modified from 1 and 5).

cal history and a clinical exploration of deglutition at the patient's bedside.

1. Clinical history. Dysphagia for solids suggests the presence of an obstructive difficulty, whereas dysphagia for liquids suggests the presence of a neurogenic dysphagia. Nasal regurgitation, the need for multiple swallows of a small bolus (fractioning), and a history of repeat respiratory infection also points to neurogenic dysphagia. The presence of choking, coughing or a wet voice suggests aspiration, although $40 \%$ of aspirations are silent and not associated with cough in neurologic patients (15). A sensation of residue in the pharynx points toward pharyngeal hypomotility, common in neurodegenerative conditions. Food regurgitation may correspond to Zenker's diverticulum. It should be remembered that the location of symptoms in the neck does not allow to differentiate between a pharyngeal or esophageal origin of dysphagia. Odynophagia suggests a pharyngeal or esophageal inflammatory condition or an esophageal motor disorder. Antipsychotics, sedatives and antidepressants may well play a role in dysphagia, particularly in the elderly. Nonspecific symptoms that manifest in a continuous manner and regardless of ingestion may correspond to pharyngeal globus. Increased ingestion duration and recent weight loss indicate decreased efficacy of deglutition and potential malnutrition. Nutritional status may be accurately assessed in the clinical setting with an appropriate clinical history and minimal physical examination (7). The clinical severity of dysphagia may be quantitized by using visual analog scales for a set of clinical symptoms (8).

2. Clinical examination of deglutition. An exploration of deglutition at the patient's bedside is performed by administering boluses of differing viscosity and volume, and then observing the patient's response. To select patients who will undergo complementary studies, various authors have developed methods based on the administration of a number of water sips to check whether aspiration signs arise (9). Our team developed a method for clinical examination using boluses with volumes ranging from 3 to $20 \mathrm{~mL}$, and liquid, nectar and pudding viscosities (10). This technique allows the first two stages (oral preparatory, oral) of deglutition to be assessed, and we also use it as a screening method -together with the clinical history, overall neurological examination, and assessment of nutritional status- to select patients who must undergo videofluoroscopy. Although this clinical examination method may provide data on the type of bolus (volume and viscosity) that is most appropriate for the patient, it must be emphasized that patients with suspected efficacy or safety impairment should undergo videofluoroscopy (11). 


\section{Complementary examinations: videofluoroscopy and pharyngoesophageal manometry}

Videofluoroscopy (VF) is a dynamic radiological technique by which a sequence of both lateral and postero-anterior images may be obtained following the oral administration of a water-soluble contrast in several volumes (3-20 mL) and 3 distinct viscosities (liquid, nectar and pudding) (11-13). It is currently considered the gold standard technique for the study of oropharyngeal dysphagia, even though information provided by pharyngoesophageal manometry is occasionally required to complement it $(1,14,15)$. The goals of videofluoroscopy are to assess deglutition's safety and efficacy, to characterize swallowing alterations in terms of videofluoroscopic signs, to evaluate the effectiveness of treatments, and to obtain quantitative data on oropharyngeal biomechanics (11).

\section{Videofluoroscopic signs during the oral stage}

Major signs of impaired efficacy during the oral stage include apraxia and decreased control and bolus propulsion by the tongue. Many patients present with deglutitional apraxia (difficulty, delay or inability to initiate the oral stage) following a CVA. This symptom is also seen in patients with Alzheimer's dementia and patients with diminished oral sensitivity. Impaired lingual control (inability to form the bolus) or propulsion results in oral or vallecular residue when alterations occur at the base of the tongue. The main sign regarding safety during the oral stage is glossopalatal (tongue-soft palate) seal insufficiency, a serious dysfunction that results in the bolus falling into the hypopharynx before the triggering of the pharyngeal motor pattern and while the airway is still open, which causes preswallowing aspiration.

\section{Videofluoroscopic signs during the pharyngeal stage}

Major videofluoroscopic signs of efficacy during the pharyngeal stage include hypopharyngeal residue and impaired aperture of the upper esophageal sphincter (UES), which are studied by using pharyngoesophageal manometry in combination. Symmetric hypopharyngeal residues in both pyriform sinuses result from weak pharyngeal contraction, which is fairly common in patients with neurodegenerative disease. Patients with CVA may exhibit unilateral residue as a consequence of unilateral pharyngeal paralysis.

Videofluoroscopic signs of safety during the pharyngeal stage include a slow or uncoordinated pharyngeal motor pattern, and penetrations and/or aspirations. Penetration refers to the entering of contrast into the laryngeal vestibule within the boundaries of the vocal cords. When aspiration occurs, contrast goes beyond these cords and into the tracheobronchial tree (Fig. 2). The potential of videofluoros- copy regarding image digitalization and quantitative analysis currently allows accurate motor pattern measurements in patients with dysphagia (Fig. 3). A slow closure of the laryngeal vestibule and a slow aperture of the upper esophageal sphincter (as seen in figure 3 ) are the most characteristic aspiration-related parameters (16). When this interval is above 0.24 seconds, the possibility of an aspiration has been estimated as very high (16). Penetration and aspiration may also result from an insufficient hyoid and laryngeal elevation, which would fail to protect the airway. A high, permanent post-swallow residue may lead to postswallow aspiration, since the hypopharinx is full of contrast when the patient inhales after swallowing, and then contrast passes directly into the airway.
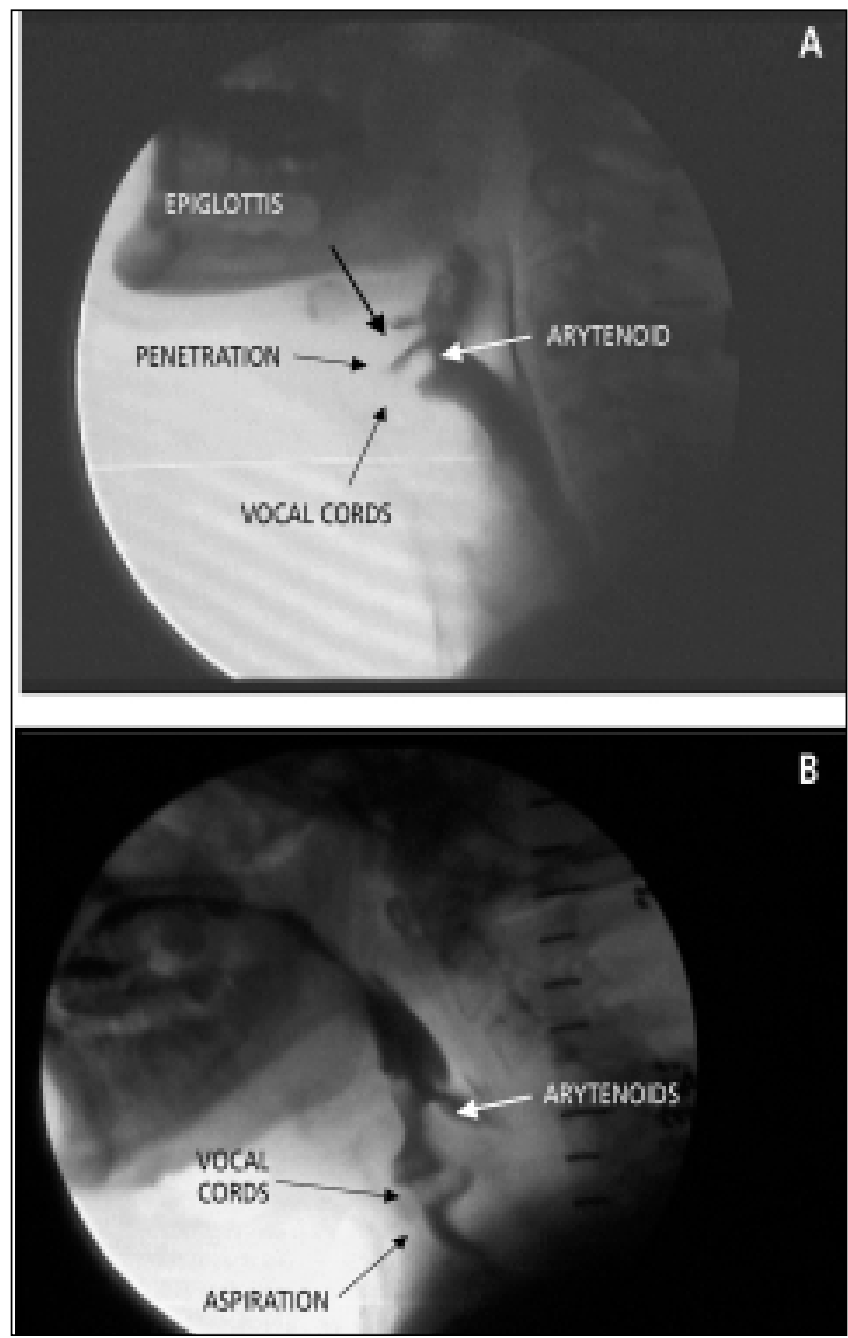

Fig. 2.- Videofluoroscopic evidence of safety during deglutition's pharyngeal stage: A) contrast penetration into the laryngeal vestibule within the boundaries of the vocal cords; B) aspiration into the tracheobronchial tree

Signos videofluoroscópicos de seguridad de la fase faríngea de la deglución: A) penetración de contraste en el vestíbulo laríngeo sin soprepasar las cuerdas vocales; B) aspiración al árbol traqueobronquial. 


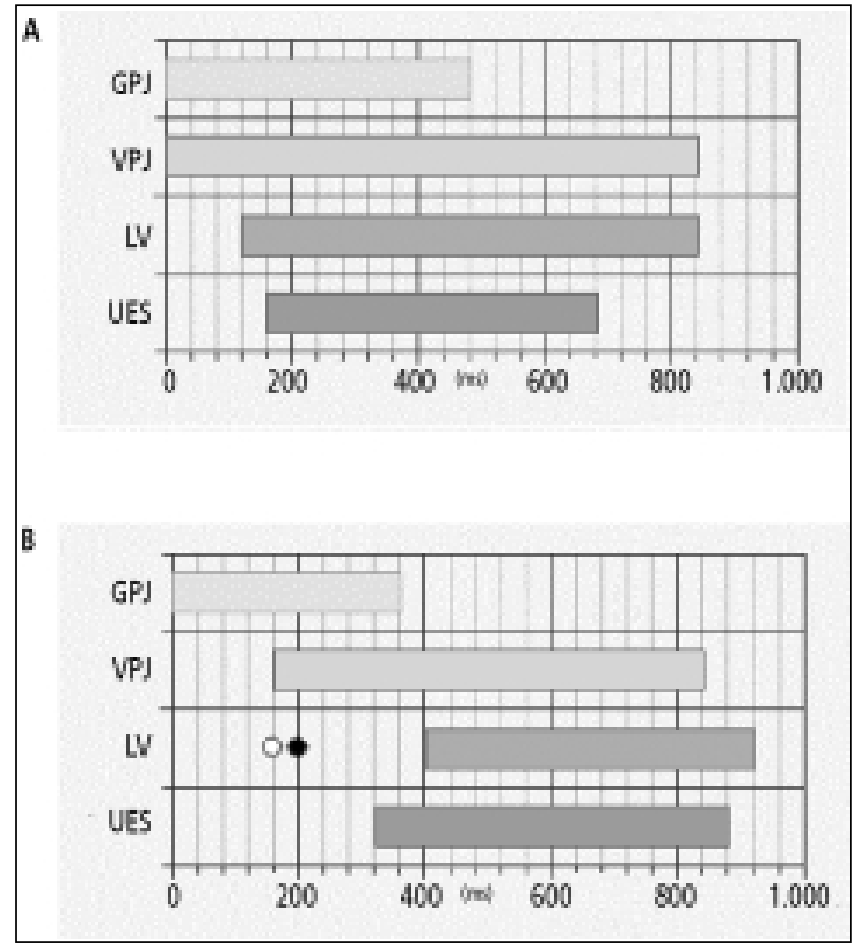

Fig. 3.- Time configuration of the pharyngeal motor pattern during the ingestion of a bolus consisting of $5 \mathrm{~mL}$ of viscous fluid: A) healthy individual; B) configuration in a patient with neurogenic dysphagia associated to ALS. An increased total duration of the deglutition's pharyngeal motor pattern may be seen, as well as a delayed closure of the laryngeal vestibule and aperture of the upper sphincter. The white dot indicates the time when contrast penetrates into the laryngeal vestibule, and the black dot indicates passage into the tracheobronchial tree (aspiration). GPJ = glossopalatal junction, VPJ = velopalatal junction, LV = laryngeal vestibule, UES = upper esophageal sphincter

Configuración temporal del patrón motor deglutorio faríngeo durante la ingesta de un bolo de $5 \mathrm{ml}$ de viscosidad líquida: A) individuo sano; B) configuración en un paciente con disfalgia neurógena asociada a ELA. Se observa un incremento en la duración total del patrón motor deglutorio faríngeo y un retardo en el cierre del vestíbulo laríngeo y de la apertura del esfínter superior. El punto blando indica el momento de la penetración de contraste en el vestíbulo laríngeo y el punto negro indica el paso al árbol traqueobronquial (aspiración). GPJ = sello glosopalatino; VPJ = sello velopalatino; $L V=$ vestíbulo laríngeo; UES = esfínter esofágico superior.

\section{Pharyngoesophageal manometry}

Most useful parameters supplied by pharyngoesophageal manometry in patients with oropharyngeal dysphagia include amplitude of pharyngeal contraction, extent of upper esophageal sphincter (UES) relaxation, amplitude and propagation of esophageal peristalsis, and the coordination thereof $(14,15)$. In normal individuals pharyngeal contraction occurs during UES relaxation, and the high compliance of UES allows the sphincter to fully relax during the ingestion of both $1 \mathrm{~mL}$ and $20 \mathrm{~mL}$ boluses (Fig. 4A). Pharyngoesophageal manometry is essential in the differential diagnosis of UES aperture disorders seen

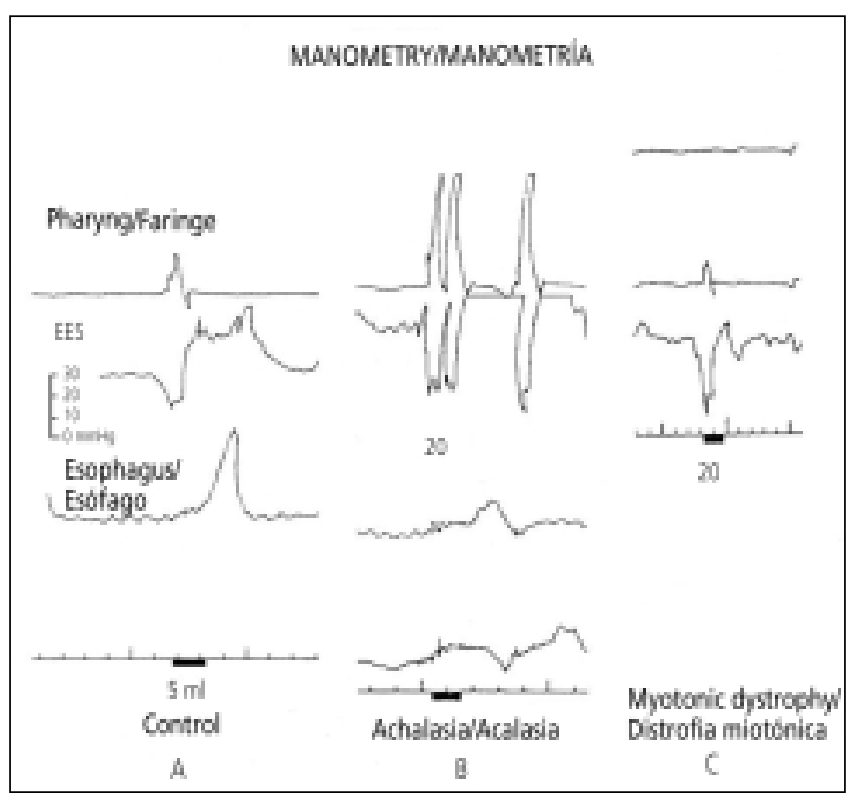

Fig. 4.- Pharyngoesophageal manometry patterns: A) healthy individual; B) obstructive pattern in a patient with Zenker's diverticulum, preserved pharyngeal contraction, increased residual pressure, and incomplete relaxation of UES; C) propulsive pattern in a patient with neurodegenerative disease, weak pharyngeal contraction, and adequate UES aperture and relaxation

Patrones de manometría faringoesofágica: A) individuo sano; B) patrón obstructivo e un paciente con divertículo de Zenker, contracción faríngea preservada, aumento de la presión residual y relajación incompleta del EES; C) patrón propulsivo en un paciente con una enfermedad neurodegenerativa, contracción faríngea débil, adecuada apertura y relajación del EES.

during videofluoroscopy, and to select an appropriate treatment option.

In patients with Zenker's diverticulum, and also in patients who fail to develop this type of diverticulum but suffer from dysphagia, cricopharyngeal muscle fibers are replaced by connective tissue, which results in fibrosis and decreased sphincter compliance. In these patients manometry shows a so-called obstructive pattern (Fig. 4B) characterized by a pharyngeal wave with preserved amplitude, and a volume-dependent increase in sphincter residual pressure (incomplete relaxation) as a consequence of high flow and resistance (17). This pattern is also seen in patients with Parkinson's disease as a result of extrapyramidal rigidity, which prevents UES relaxation (18). Many patients with neuromuscular conditions also exhibit incomplete UES aperture during videofluoroscopy. In these patients manometry shows a so-called propulsive pattern characterized by decreased (even absent) pharyngeal wave and adequate upper sphincter relaxation (Fig. 4C). These patients show incomplete UES aperture during videofluoroscopy despite normal manometric relaxation, which results from lack of strength at bolus propulsion because of a weak lingual and pharyngeal contraction. 


\section{Clinical usefulness of the videofluoroscopic diagnosis program}

VF is the gold standard in the study of oropharyngeal dysphagia. Between 45 and $90 \%$ of patients with neurologic disease show impaired deglutition efficacy that may result in malnutrition and two thirds of these patients suffer from an impaired safety that may result in aspiration (2). In addition, VF may identify potential silent aspiration in $1 / 4$ to $1 / 3$ of such patients, which is not clinically diagnosable and therefore entails an extremely high risk of pneumonia (11).

\section{MANAGEMENT OF OROPHARYNGEAL DYSPHAGIA}

Management strategies for oropharyngeal dysphagia may be grouped into four major categories that may be simultaneously applied to the treatment of each individual patient (21). During videofluoroscopy the needed combination of strategies may be selected to compensate each patient's specific deficiency, and its usefulness to treat the patient's symptoms may be explored:

1. Postural strategies. Verticality and symmetry should be sought during the patient's ingestion. Attention must be paid to controlling breathing and muscle tone. Postural strategies are easy to adopt -they cause no fatigue- and allow modification of oropharyngeal and bolus path dimensions. Anterior neck flexion protects the airway (22); posterior flexion facilitates gravitational pharyngeal drainage and improves oral transit velocity; head rotation toward the paralyzed pharyngeal side directs food to the healthy side, increases pharyngeal transit efficacy, and facilitates UES aperture (23); deglutition in the lateral or supine decubitus protects from aspirating hypopharyngeal residues.

2. Change in bolus volume or viscosity. In patients with neurogenic dysphagia, bolus volume reductions and bolus viscosity increases significantly improve safety signs, particularly regarding penetration and aspiration. Viscosity is a physical property that can be measured and expressed in international system units by the name of Pa.s. The prevalence of penetrations and aspirations is maximal with fluids (20 mPa.s) and decreases with nectar (270 mPa.s) and pudding (3900 mPa.s) viscosity boluses (24). Modifying the texture of liquids is particularly important to ensure that patients with neurogenic or ageing-associated dysphagia remain adequately hydrated and aspiration-free (25). This may be easily achieved by using appropriate thickening agents, which are readily available nowadays.

3. Sensorial enhancement strategies. Oral sensorial enhancement strategies are particularly useful in patients with apraxia or impaired oral sensitivity (very common in elderly patients). The focus of other strategies is the initiation or acceleration of the swallowing pharyngeal motor pattern. Most sensorial enhancement strategies in- clude a mechanical stimulation of the tongue, bolus modifications (volume, temperature, and taste) or a mechanical stimulation of the pharyngeal pillars. Acid flavours such as lemon or lime, and cold substances such as ice cream or ice, trigger the mechanism of deglutition (26). The development of physical or drug-based strategies to accelerate the pharyngeal motor pattern represents a relevant field of research for the management of neurogenic dysphagia and ageing-associated dysphagia.

4. Neuromuscular praxis. The goal is improving the physiology of deglutition (the tonicity, sensitivity, and motility of oral structures, particularly the lips and tongue, and pharyngeal structures). Lingual control and propulsion may be improved by using rehabilitation and biofeedback techniques. Of late, the rehabilitation of hyoid muscles with cervical flexion exercises has been shown to improve hyoid and laryngeal elevation, to increase UES aperture, to reduce pharyngeal residue, and to improve dysphagia symptoms in patients with neurogenic dysphagia (20). The management of patients with impaired UES aperture as a consequence of propulsive deficiencies should be basically oriented to increase bolus propulsion force and to rehabilitate the extrinsic mechanisms of UES aperture, particularly the activity of hyoid muscles (20).

5. Specific swallowing maneuvers. These are maneuvers the patient must be able to learn and perform in an automated way. Each maneuver is specifically directed to compensate specific biomechanical alterations $(12,21)$ :

-Supraglottic (super/supraglottic) deglutition: its aim is to close the vocal folds before and during deglutition in order to protect the airway from aspiration. It is useful in patients with penetrations or aspirations during the pharyngeal stage or slow pharyngeal motor pattern.

-Stress or forced deglutition: its aim is to increase the posterior motion of the tongue base during deglutition in order to improve bolus propulsion. It is useful in patients with low bolus propulsion.

-Double deglutition: its aim is to minimize postswallow residue before a new inspiration. It is useful in patients with postswallow residue.

-Mendelsohn's maneuver: it allows for increased extent and duration of laryngeal elevation and therefore increased duration and amplitude of UES aperture.

6. Surgical/drug-based management of UES. Identifying an obstructive pattern at the UES allows patient management using a surgical cricopharyngeal section (17) or an injection of botulin toxin (19).

VF will help in treatment selection depending upon the severity of efficacy or safety impairment in each individual patient: a) patients with mild efficacy alterations and correct safety may have a family-supervised restriction-free diet; b) in patients with moderate alterations dietary changes will be introduced aiming at decreasing the volume and increasing the viscosity of the alimentary bolus; c) patients with severe alterations will require additional strategies based upon increased viscosity and the introduction of postural techniques, active maneuvers 
and oral sensorial enhancement; and d) there is a group of patients with alterations so severe that cannot be treated despite using rehabilitation techniques; in these patients VF allows to objectively demonstrate the inability of the oral route and the need to perform a percutaneous endoscopic gastrostomy (27). Even though no absolute criteria exist, a number of teams tend to indicate gastrostomy in: a) patients with severe alterations of efficacy during the oral or pharyngeal stages, or with malnutrition; b) patients with safety alterations during the pharyngeal stage that do not respond to rehabilitation; and c) patients with significant silent aspirations, particularly in neurodegenerative conditions. For most patients requiring gastrostomy a small percentage of food may still be safely administered through the oral route.

\section{CONCLUSIONS}

The way to approach oropharyngeal dysphagia and its clinical relevance may be summarized in four points:

1. Oropharyneal dysphagia is a severe symptom with both nutritional and respiratory complications that are life-threatening.

2. It is a scarcely assessed and studied symptom in the clinical setting despite the availability of specific methods for its diagnosis, as is the case with videofluoroscopy and pharyngoesophageal manometry. Figure 1 summarizes a diagnostic algorithm for patients with oropharyngeal dysphagia.

3. Therapeutic strategies exist for patients with oropharyngeal dysphagia, including changes in bolus volume and viscocity, postural changes, praxis, active maneuvers, rehabilitation procedures, and sensorial enhancement techniques, all of them of well-proven efficacy and capable of preventing complications. These techniques fail to treat some patients where gastrostomy must be indicated to prevent respiratory and nutritional complications.

4. The diagnosis and treatment of patients with oropharyngeal dysphagia depend on the work of a multidisciplinary team of professionals made up of physicians, nurses, language therapists, dieticians, and the patient's family.

\section{ACKNOWLEDGMENTS}

Institut Guttmann: Dr. M. Bernabeu, Dr. S. Ramón, Dr. Orient (Brain Damage Unit), Mrs. M. Martinell (Language Therapist), Mr. P. Corpas (Radiodiagnosis).

Hospital de Mataró. Dr. P. Fossas, Dr. Palomeras (Neurology), Dr. M. Cabré (Geriatrics), Dr. M. Girvent (Surgery, nutritional studies), Mrs. M. Arús (Dietician), Mrs. R. Monteis (Geriatric Nurse), Mrs. E. Palomeras.

Fundació de Gastroenterlogía Dr. F. Vilardell. Mr. A. Blanco (Telecommunications Engineer), Mr. R. Farré, Mrs. Emma Martínez (in vitro viscosity studies).

Hospital de Sant Pau: Dr. J. Pradas, Dr. Rojas (Neuro- logy Dept.), Dr. R. Güell, Dr. P. Antón (Pneumology Dept.), Mrs. M. Casanovas (Language Pathology School). Fundació Dr. Vilardell. Mrs. G. Foyo.

Clinical trials prformed with the support of FIS 98/0794), Novartis Consumer Health S.A. (FCG/NHC1), Fundació de Gastroenterología Dr. F. Vilardell, and Filial del Maresme de la Academia de Ciencies Mediques de Catalunya i Balears.

\section{REFERENCES}

1. Cook IJ, Kahrillas PJ. AGA Technical review on management of oropharyngeal dysphagia. Gastroenterology 1999; 116: 455-78.

2. Dysphagia: a tertiary and specialised medical problem. www.dysphagiaonline.com.

3. Diagnosis and treatment of Swallowing Disorders in Acute-Care Stroke Patients. Summary, Evidence Report/Technology Assessment. Agency for Health Care Policy and Research. Number 8, March 1999. Rockville, MD, USA. www.ahrq.gov/clinic/epcsums/dysphsum.htm

4. Kerr JE, Bath PMW. Interventions for dysphagia in acute stroke (Protocol for a Cochrane Review. In: The Cochrane Library, Issue 3, 1999.

5. Disfagia Neurógena: Evaluación y tratamiento. Blocs 14. Fundació Institut Guttmann (ed. Badalona, 2002). www.guttmann.com

6. Buchholz DW. Neurogenic dysphagia: what is the cause when the cause is not obvious? Dysphagia 1994; 9: 245-55.

7. Detsky AS, McLaughlin JR, Baker JP, Johnston N, Whittaker S, Mendelson R, et al. What is subjective global assessment of nutritional status? JPEN 1987; 11: 8-13.

8. Wallace KL, Middleton S, Cook IJ. Development and validation of a self-report symptom inventory to assess the severity of oral-pharyngeal dysphagia. Gastroenterology 2000; 118: 678-87.

9. DePippo KL, Holas MA, Reding MJ. Validation of the 3-oz water swallow test for aspiration following stroke. Arch Neurol 1992; 49: 1259-61.

10. Clavé P. Protocolo de ensayo clínico: Evaluación videofluoroscópica del efecto terapéutico de resource espesante en pacientes con disfagia orofaríngea. FCG/Novartis-1, 2001.

11. Clavé P. Videofluoroscopic diagnosis of oropharyngeal dysphagia. Nutrition Matters 2001; 3: 1-2.

12. Logemann JA. Manual for the videofluorographic study of swallowing. $2^{\text {nd }}$ ed. Pro-ed, Austin, USA, 1993.

13. Clavé P. Diagnóstico de la disfagia neurógena: Exploraciones complementarias. En: Disfagia neurógena: evaluación y tratamiento. Blocs 14. Fundació Institut Guttmann (ed. Badalona). 2002. p. 19-27.

14. Kahrilas PJ, Logemann JA, Lin S, Ergun GA. Pharyngeal clearance during swallowing: a combined manometric and videofluoroscopic study. Gastroenterology 1992; 103: 128-36.

15. Fuster M, Negredo E, Cadafalch J, Domingo J, Illa I, Clavé P. HIVassociated polimyositis with life-threatening myocardial and esophageal involvement. Arch Intern Med 1999; 159: 1011-2.

16. Kahrilas PJ, Lin S, Rademaker A, Logemann JA. Impaired deglutitive airway protection: a videofluoroscopic analysis of severity and mechanism. Gastroenterology 1997; 113: 1457-64.

17. Shaw DW, Cook IJ, Jamieson GG, Gabb M, Simula MEW, Dent. Influence of surgery on deglutitive upper oesophageal sphincter mechanics in Zenker's diverticulum. Gut 1996; 38: 806-11.

18. Ali GN, Wallace KL, Schwartz R, deCarle J, Zagami AS, Cook IJ. Mechanisms of oral-pharyngeal dysphagia in patients with Parkinson's disease. Gastroenterology 1996; 110: 383-92.

19. Ravich WJ. Botulin toxin for UES dysfunction: Theraphy or poison? Editorial. Dysphagia 2001; 16: 168-70.

20. Shaker R, Easterling C, Kern M, Nitschke, Massey B, Daniels S, et al. Rehabilitation of swallowing by exercise in tube-fed patients with pharyngeal dysphagia secondary to abnormal UES openinng. Gastroenterology 2002. p. 1314-21.

21. Logemann JA. Dysphagia: Evaluation and Treatment. Folia Phoniatr Logop 1995; 47: 121-9. 
22. Logemann JA, Kahrilas PJ, Kobara M, Vakil NB. The benefit of head rotation on pharyngoesophageal dysphagia. Arch Phys Med Rehabil 1989; 70: 767-71.

23. Rasley A, Logemann JA, Kahrilas PJ, Rademaker AW, Pauloski BR, Dodds WJ. Prevention of barium aspiration during videofluoroscopic swallowing studies: value of change in posture. Am J Roentgenol 1993; 160: 1005-9.

24. Clavé P, Terré R, de Kraa M, Girvent, Farré R, Martínez E, et al. Therapeutic effect of increasing bolus viscosity in neurogenic dysphagia. ESPEN, 2003.
25. Clavé P, de Kraa M. Diagnóstico y tratamiento de la disfagia orofaríngea en el anciano. En: Sociedad española de Geriatría y Gerontología, y Sociedad Española de Nutrición Básica y Aplicada (eds). Manual de Práctica Clínica de Nutrición en Geriatría. Madrid, 2003.

26. Logemann JA, Pauloski BR, Colangelo L, Lazarus C, Fujiu M, Kahrilas P. Effects of a sour bolus on oropharyngeal swallowing measures in patients with neurogenic dysphagia. J Speech Hear Res 1995; 38: 556-63.

27. Mazzini L, Corrà T, Zaccala M, Mora G, Del Piano, M, Galante. Percutaneous endoscopic gasrostomy and enteral nutrition in amyotrophc lateral sclerosis. J Neurol 1995; 242: 695-8.

\title{
Actitud a seguir ante una disfagia orofaríngea
}

\author{
P. Clavé1,2, R. Terré1, M. de Kraa² y M. Serra² \\ ${ }^{1}$ Unidad de Neurofisiología Digestiva. Institut Guttmann. Badalona. Barcelona. ${ }^{2}$ Unidad de Exploraciones Funcionales \\ Digestivas. Hospital de Mataró. Barcelona
}

\section{INTRODUCCIÓN}

La disfagia es un síntoma que se refiere a la dificultad o disconfort para mover el bolo alimentario desde la boca al estómago. Desde un punto de vista anatómico la disfagia puede deberse a disfunciones orofaríngeas o esofágicas y desde un punto de vista fisiopatológico a causas estructurales o funcionales. La prevalencia de la disfagia orofaríngea funcional en pacientes con enfermedades neurológicas es muy elevada: afecta a más del $30 \%$ de pacientes que han sufrido un AVC, su prevalencia en la enfermedad de Parkinson es del 52-82\%; es el síntoma inicial del $60 \%$ de pacientes con esclerosis lateral amiotrófica (ELA); afecta al $40 \%$ de pacientes con miastenia gravis, al $44 \%$ de pacientes con esclerosis múltiple, hasta el $84 \%$ de pacientes con Alzheimer, o a más del $60 \%$ de pacientes ancianos institucionalizados (1-5). La severidad de la disfagia orofaríngea puede variar desde una dificultad moderada hasta la total imposibilidad para la deglución.

La disfagia orofaríngea puede originar dos grupos de complicaciones de gran trascendencia clínica:

1. Si se produce una disminución de la eficacia de la deglución el paciente va a presentar malnutrición y/o deshidratación.

2. Si se produce una disminución de la seguridad de la deglución se va a producir o un atragantamiento con obstrucción de la vía aérea, o más frecuentemente una aspiración traqueobronquial que puede ocasionar una neumonía en el $50 \%$ de los casos con una mortalidad asociada de hasta el $50 \%$ (1).

\section{OBJETIVO}

Establecer un conjunto de recomendaciones clínicas con el objetivo de facilitar el diagnóstico y el tratamiento de los pacientes con disfagia orofaríngea de tipo funcional.

\section{MÉTODO}

Esta revisión acerca de la actitud a seguir ante una disfagia orofaríngea funcional se fundamenta en la discusión de las recomendaciones formuladas en documentos de consenso basados "mejor evidencia y práctica médica posible" por los siguientes grupos de expertos:

- AGA Technical Review on Management of Oropharyngeal Dysphagia (1).

-www.dysphagiaonline.com (2).

- Evidence Report/Technology Assessment. Agency for Health Care Policy and Research. EE.UU. (3).

-Interventions for dysphagia in acute stroke. Cochrane Review (4).

-Disfagia Neurógena: Evaluación y Tratamiento. Fundació Institut Guttmann. Hospital de Neurorehabilitación (5).

\section{LA DEGLUCIÓN NORMAL}

La deglución normal se divide en cuatro grandes fases, cualquiera de ellas (con frecuencia más de una) puede estar afectada y originar disfagia: 
1. La fase oral preparatoria está bajo control voluntario y su objetivo es la masticación y la formación del bolo.

2. La fase oral es también voluntaria y se caracteriza por la propulsión del bolo por acción de la lengua.

3. La fase faríngea es involuntaria, y se inicia por la estimulación de mecanorreceptores faríngeos que envían información al SNC y causan el disparo del denominado patrón motor deglutorio faríngeo (reflejo deglutorio) caracterizado por una secuencia fija y ordenada de acontecimientos motores que ocasionan el cierre de la nasofaringe (elevación del paladar blando) y de la vía respiratoria (elevación y desplazamiento anterior del hioides, descenso de la epiglotis y cierre de cuerdas vocales), apertura del esfínter esofágico superior (EES) y la contracción de los músculos constrictores faríngeos. La lengua es la principal responsable de la propulsión del bolo y la principal misión de los constrictores faríngeos es aclarar los residuos del bolo que quedan en la hipofaringe.

4. La fase esofágica se inicia con la apertura del EES seguido de la peristalsis esofágica.

\section{FISIOPATOLOGÍA DE LA DISFAGIA}

La disfagia puede producirse por una amplia variedad de alteraciones estructurales que dificulten o impidan la reconfiguración de la orofaringe durante la deglución desde una vía respiratoria a una vía digestiva o que obstaculicen el paso del bolo, y/o alteraciones funcionales que alteren la propulsión del bolo o la configuración faríngea. Entre las anormalidades estructurales más frecuentes se incluyen los tumores esofágicos y del área ORL, osteofitos cervicales, estenosis esofágicas -frecuentemente postquirúrgicas-, las alteraciones de apertura del esfínter superior (barra del cricofaríngeo, acalasia del cricofaríngeo) y el diverículo de Zenker. Sin embargo, con frecuencia la disfagia orofaríngea es una manifestación clínica de una enfermedad sistémica, una enfermedad neurológica, o está asociada al envejecimiento. Muy frecuentemente la disfagia precede a otros síntomas neurológicos (6). Las enfermedades neurológicas pueden causar también la alteración de la función del músculo liso o estriado del esófago, o de las motoneuronas del plexo mientérico que controlan la amplitud y peristalsis esofágica, y la relajación del esfínter esofágico inferior. Además, la disfagia esofágica puede ser un frecuente síntoma de enfermedad por reflujo gastroesofágico cuya prevalencia está también aumentada en muchos colectivos de pacientes con disfagia neurógena.

\section{DIAGNÓSTICO DE LA DISFAGIA}

\section{El equipo multidisciplinar de disfagia. Unidades de disfagia}

El diagnóstico y el tratamiento de la disfagia orofaríngea requiere un abordaje multidisciplinar. El equipo multidisciplinar de disfagia debe incluir conocimientos de diferentes dominios profesionales: enfermeras, logopedas, gastroenterólogos, ORL, neurólogos, médicos rehabilitadores, cirujanos, dietistas, radiólogos, geriatras, etc. El ejemplo de operatividad de diversos de estos equipos ha puesto de manifiesto lo poco importante que es la formación de origen de sus miembros y lo importante que resulta el desarrollo de habilidades como grupo para cubrir el espectro de las necesidades diagnósticas y terapéuticas de los pacientes con disfagia de acuerdo a criterios comunes. Los objetivos del equipo multidisciplinar de disfagia son: a) la identificación de los pacientes con disfagia; b) el diagnóstico de cualquier etiología médica o quirúrgica de disfagia que tenga posibilidades de un tratamiento específico, la exclusión de los tumores del área ORL y esofágicos, y la enfermedad por reflujo gastroesofágico y sus complicaciones; c) la caracterización de las alteraciones biomecánicas orofaríngeas responsables de la disfagia en cada paciente; y d) el diseño de un conjunto de estrategias terapéuticas destinadas a proporcionar una deglución eficaz y segura al paciente, o proporcionar una vía alternativa a la alimentación oral en base a datos objetivos y reproducibles. Es muy importante involucrar a la familia del paciente en el proceso diagnóstico y terapéutico. Es frecuente que los recursos diagnósticos y terapéuticos se concentren en las denominados "unidades o centros de disfagia" (swallowing centers), que actúan como centros de referencia en los que es posible ofrecer a los pacientes con disfagia orofaríngea, procedentes de diferentes centros hospitalarios, todos los recursos diagnósticos y todos los tratamientos $\mathrm{u}$ orientaciones terapéuticas que necesiten.

\section{Programa de diagnóstico de disfagia orofaríngea}

El algoritmo diagnóstico de la figura 1 resume la estrategia diagnóstica de los pacientes con disfagia orofaríngea. Una vez descartadas las causas estructurales (en especial los tumores ORL y esofágicos), y establecido el diagnóstico de disfagia orofaríngea de origen funcional, el objetivo del programa de diagnóstico es evaluar las 2 características que definen la deglución: a) eficacia, capacidad de que el paciente ingiera la totalidad de las calorías y el agua que necesita para estar bien nutrido e hidratado; y b) seguridad, capacidad de que la ingesta del agua y las calorías necesarias sin que se produzcan complicaciones respiratorias. Para evaluar estas dos características de la deglución disponemos de dos grupos de métodos de diagnóstico: a) los métodos clínicos como la historia clínica específica y la exploración clínica de la deglución; y b) la exploración de la deglución mediante exploraciones complementarias específicas: videofluoroscopia y manometría faringoesofágica.

\section{Métodos clínicos: historia clínica y exploración clínica de la deglución}

El programa de diagnóstico de la disfagia orofaríngea se inicia con los métodos clínicos (Fig. 1). El objetivo es 


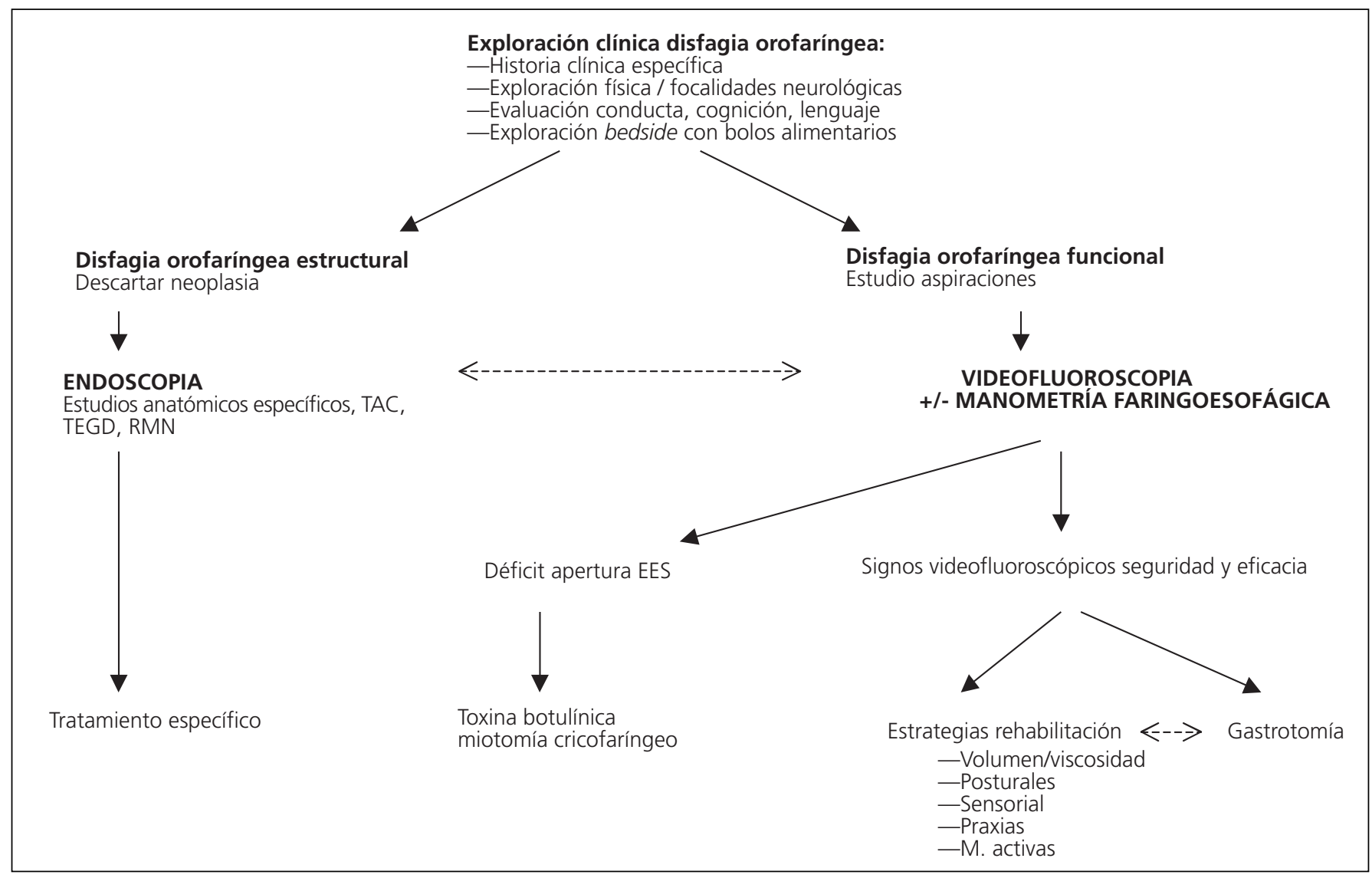

Fig. 1.- Algoritmo diagnóstico y terapéutico para los pacientes con disfagia orofaríngea (modificado de 1 y 5).

determinar si los síntomas del paciente corresponden a una disfagia orfaríngea, decidir si el paciente va a requerir exploraciones complementarias, e identificar las posibles complicaciones nutricionales y respiratorias. La exploración debe incluir la valoración de aspectos conductuales, cognitivos, y de lenguaje -necesarios para evaluar los mecanismos de disfagia y las posibilidades de tratamiento-, y es imprescindible descartar cualquier focalidad neurológica. Los dos métodos clínicos principales son la historia clínica específica y la exploración clínica de la deglución en la cabecera del paciente.

1. La historia clínica. La disfagia a sólidos sugiere la existencia de un problema obstructivo mientras que la disfagia a líquidos sugiere una disfagia neurógena. La regurgitación nasal, la necesidad de múltiples degluciones para un bolo pequeño (fraccionamiento) y una historia de infecciones respiratorias repetitivas también orienta a una disfagia neurógena. La presencia de atragantamientos, tos o voz húmeda sugieren una aspiración, aunque en pacientes neurológicos, hasta el $40 \%$ de aspiraciones son silentes y no se acompañan de tos (1-5). La sensación de residuo en la faringe orienta a una hipomotilidad faríngea frecuente en enfermedades neurodegenerativas. La regurgitación de alimentos puede corresponder a un divertículo de Zenker. Es importante recordar que la localización cervical de los síntomas del paciente no permite distin- guir entre disfagia de causa faríngea o esofágica. La odinofagia sugiere un proceso inflamatorio faríngeo o esofágico o un trastorno motor esofágico. Es posible que fármacos neurolépticos, sedantes o antidepresivos participen en la disfagia del paciente, especialmente en ancianos. Si los síntomas son inespecíficos y se manifiestan de forma continua e independiente de la ingesta pueden corresponder a un globo faríngeo. El aumento del tiempo en cada ingesta y la pérdida de peso reciente indican una disminución de la eficacia de la deglución y la posibilidad de malnutrición. El estado nutricional puede evaluarse clínicamente de forma precisa mediante una adecuada historia clínica y un mínima exploración física (7). La severidad clínica de la disfagia puede cuantificarse mediante la aplicación de escalas analógico-visuales a una batería de síntomas clínicos (8).

2. La exploración clínica de la deglución. La exploración de la deglución en la cabecera del paciente se realiza administrando al paciente bolos de viscosidad y volumen diferente, y observando sus reacciones. Diversos autores han desarrollado métodos basados en administrar al paciente diversos sorbos de agua y observar si presenta signos de aspiración para seleccionar los pacientes que recurrirán exploraciones complementarias (9). Nuestro grupo ha desarrollado un método de exploración clínica mediante bolos en un rango de volumen de 3 a $20 \mathrm{ml}$ y viscosidad líquida, 
néctar y pudding (10). Esta técnica nos permite evaluar las dos primeras fases (oral preparatoria, oral) de la deglución y también la utilizamos como método de screening junto con la historia clínica, una exploración neurológica general y la evaluación del estado nutricional para seleccionar a los pacientes que deben ser estudiados mediante videofluoroscopia. Aunque el método de exploración clínica ofrezca datos acerca del tipo de bolo (volumen y viscosidad) más adecuado para el paciente, es importante recalcar que un paciente en el que se sospeche una alteración de la eficacia o seguridad de la deglución debería ser estudiado mediante videofluoroscopia (11).

\section{Exploraciones complementarias: videofluoroscopia y manometría faringoesofágica}

La videofluoroscopia (VFS) es una técnica radiológica dinámica que consiste en la obtención de una secuencia en perfil lateral y anteroposterior de la ingesta de diferentes volúmenes $(3-20 \mathrm{ml})$ de 3 viscosidades diferentes (líquido, néctar y pudding) de un contraste hidrosoluble (11-13). Actualmente se considera esta técnica como el patrón de oro del estudio de la disfagia orofaríngea, aunque en ocasiones los estudios deben complementarse con la información proporcionada por la manometría faringoesofágica $(1,14,15)$. Los objetivos de la videofluoroscopia son evaluar la seguridad y la eficacia de la deglución, caracterizar las alteraciones de la deglución en términos de signos videofluoroscópicos, evaluar la eficacia de los tratamientos y obtener datos cuantitativos de la biomecánica orofaríngea (11).

\section{Signos videofluoroscópicos de la fase oral}

Los principales signos de alteraciones de la eficacia de la fase oral son la apraxia y la disminución del control y de la propulsión lingual del bolo. Muchos pacientes presentan apraxia deglutoria (dificultad, retraso o imposibilidad en iniciar la fase oral) después de un AVC. Este síntoma también se observa en pacientes con Alzheimer y en pacientes con una disminución de la sensibilidad oral. Las alteraciones del control lingual (imposibilidad de formar el bolo) o de su propulsión van a causar un residuo oral o en la vallécula cuando la alteración es de la base de la lengua. El principal signo acerca de la seguridad de la fase oral es la insuficiencia del sello palatogloso (lengua-paladar blando), disfunción muy grave que va a originar la caída del bolo a la hipofaringe antes del disparo del patrón motor deglutorio faríngeo y mientras la vía respiratoria está todavía abierta, provocando una aspiracion predeglutoria.

\section{Signos videofluoroscópicos de la fase faríngea}

Los principales signos videofluoroscópicos de la eficacia de la fase faríngea son el residuo hipofaríngeo y las alteraciones de apertura del esfínter esofágico superior (EES), que se estudian de forma combinada con la manometría faringoesofágica. Un residuo hipofaríngeo simétrico en ambos senos piriformes es debido a una contracción faríngea débil, muy frecuente en los pacientes con enfermedades neurodegenerativas. Los pacientes con AVC pueden presentar un residuo unilateral como consecuencia de una parálisis faríngea unilateral.

Los signos videofluoroscópicos de la seguridad de la fase faríngea son la lentitud o la incoordinación del $p a$ trón motor deglutorio faríngeo y las penetraciones y/o aspiraciones. Se denomina penetración a la entrada de contraste en el vestíbulo laríngeo sin rebasar las cuerdas vocales. Si se produce una aspiración el contraste atraviesa las cuerdas y pasa al árbol traqueobronquial (Fig. 2). La posibilidad de digitalización y análisis cuantitativo de la imágenes de la videofluoroscopia permite en la actualidad una medida precisa del patrón motor en los pacientes con disfagia (Fig. 3). La lentitud en el cierre del vestíbulo laríngeo y la lentitud en la apertura del esfínter esofágico superior (como la que se observa en la figura 3) son los parámetros más relacionados con la posibilidad de una aspiración (16). Se ha determinado que cuando este intervalo es superior a 0,24 segundos la posibilidad de aspiración es muy elevada (16). La penetración o aspiración puede estar también causada por un insuficiente ascenso hioideo y laríngeo que ocasiona una insuficiente protección de la vía respiratoria. La permanencia de un elevado residuo postdeglutorio puede conducir a aspiraciones postdeglutorias dado que cuando el paciente inspira después de la deglución se encuentra la hipofaringe llena de contraste que pasa directamente a la vía respiratoria.

\section{Manometría faringoesofágica}

Los parámetros más útiles que ofrece la manometría faringoesofágica en los pacientes con disfagia orofaríngea son la amplitud de la contracción faríngea, la amplitud de la relajación del esfínter esofágico superior (EES), la amplitud y propagación de la peristalsis esofágica y la coordinación entre estos elementos $(14,15)$. En individuos normales la contracción faríngea se produce durante la relajación del EES, y la gran distensibilidad (complianza) del EES permite que el esfínter se relaje completamente tanto durante la ingesta de $1 \mathrm{ml}$ como de $20 \mathrm{ml}$ (Fig. 4A). La manometría faringoesofágica es imprescindible para el diagnóstico diferencial de los trastornos de apertura del EES que se observan durante la videofluoroscopia, y para seleccionar su tratamiento.

En los pacientes con divertículo de Zenker, pero también en otros pacientes que no llegan a desarrollar el diverículo pero presentan disfagia, las fibras musculares del cricofaríngeo son sustituidas por tejido conectivo ocasionando la fibrosis y disminución de la distensibilidad del esfínter. En estos pacientes la manometría muestra el denominado patrón obstructivo (Fig. 4B) caracteri- 
zado por una onda faríngea de amplitud preservada, un incremento volumen-dependiente de la presión residual del esfínter (relajación incompleta) como consecuencia del elevado flujo y la resistencia (17). Este patrón se observa también en pacientes con enfermedad de Parkinson en los que está causado por la rigidez extrapiramidal que impide la relajación del EES (18). En muchos pacientes con enfermedades neuromusculares también se observa una apertura incompleta del EES durante la videofluoroscopia. En estos pacientes la manometría muestra el denominado patrón propulsivo caracterizado por la disminución (o incluso ausencia) de la onda faríngea, y la adecuada relajación del esfínter superior (Fig. 4C). En estos pacientes la apertura del EES es incompleta durante la viedofluoroscopia a pesar de la normal relajación manométrica debido a la escasa fuerza de propulsión del bolo ocasionado por la debilidad de la contracción lingual y faríngea.

\section{Utilidad clínica del programa de diagnóstico videofluoroscópico}

La VFS es el patrón de oro para el estudio de la disfagia orofaríngea. Entre el 45-90\% de los pacientes con enfermedades neurológicas presentan alteraciones de la eficacia de la deglución que pueden dar lugar a malnutrición, y 2/3 de estos pacientes presentan alteraciones de la seguridad que pueden dar lugar a aspiraciones (2). Además, la VFS permite identificar entre $1 / 3$ y un $1 / 4$ de estos pacientes que van a presentar aspiraciones silentes no diagnosticables clínicamente y que por tanto van a estar en un riesgo elevadísimo de presentar una neumonía (11).

\section{TRATAMIENTO DE LA DISFAGIA OROFARÍNGEA}

Las estrategias de tratamiento de la disfagia orofaríngea pueden agruparse en cuatro grandes grupos que pueden aplicarse simultáneamente en el tratamiento de cada paciente (21). Durante el estudio videofluoroscópico es posible seleccionar la combinación de estas estrategias necesaria para compensar el déficit específico de cada paciente y comprobar su utilidad para tratar los síntomas del paciente:

1. Estrategias posturales. Hay que buscar la verticalidad y simetría del paciente durante la ingesta. Debe prestarse atención al control de la respiración y del tono muscular. Las estrategias posturales son fáciles de adquirir -no fatigan- y permiten modificar las dimensiones de la orofaringe y de la vía que debe seguir el bolo. La flexión anterior del cuello permite proteger la vía respiratoria (22); la flexión posterior facilita el drenaje gravitatorio faríngeo y mejora la velocidad de tránsito oral; la rotación de la cabeza hacia el lado faríngeo paralizado dirige la comida al lado sano, aumenta la eficacia del tránsito faríngeo, y facilita la apertura del EES (23); la deglución en decúbito lateral o supino protege de la aspiración de un residuo hipofaríngeo.

2. Cambios de volumen y viscosidad del bolo. En los pacientes con disfagia neurógena la reducción del volumen del bolo y los incrementos de viscosidad causan una importante mejoría de los signos de seguridad, en especial de las penetraciones y aspiraciones. La viscosidad es una propiedad física que puede ser medida y se expresa en unidades del Sistema Internacional denominadas Pa.s. La prevalencia de penetraciones y aspiraciones es máxima con líquidos (20 mPa.s) y disminuye con bolos de viscosidad néctar (270 mPa.s) y pudding (3900 mPa.s) (24). La modificación de la textura de los líquidos es especialmente importante para asegurarse de que los pacientes con disfagia neurógena o asociada al envejecimiento estén adecuadamente hidratados sin que presenten aspiraciones (25). Esto puede lograrse fácilmente con el uso de agentes espesantes apropiados, fácilmente disponibles en la actualidad.

3. Estrategias de incremento sensorial. Las estrategias de incremento sensorial oral son especialmente útiles en pacientes con apraxia o alteraciones de la sensibilidad oral (muy frecuente en pacientes ancianos). También existen estrategias destinadas a iniciar o acelerar el patrón motor deglutorio faríngeo. La mayoría de estrategias de incremento sensorial comprenden la estimulación mecánica de la lengua, modificaciones del bolo (volumen, temperatura, y sabor o la estimulación mecánica de los pilares faríngeos; los sabores ácidos, como el del limón o la lima, o las sustancias frías helado, hielo) desencadenan el mecanismo de la deglución (26). El desarrollo de estrategias físicas o farmacológicas de aceleración del patrón motor deglutorio faríngeo constituyen una importante área de investigación para el tratamiento de la disfagia neurógena y de la disfagia asociada al envejecimiento.

4. Praxias neuromusculares. El objetivo es mejorar de la fisiología de la deglución (el tono, la sensibilidad y la motricidad de las estructuras orales, en especial labios y lengua, y faríngeas). Es posible mejorar el control y la propulsión lingual mediante rehabilitación y técnicas de biofeedback. Muy recientemente se ha demostrado que la rehabilitación de la musculatura hioidea mediante ejercicios de flexión cervical causa una mejoría del ascenso hioideo y laríngeo, incrementa la apertura del EES, reduce el residuo faríngeo y mejora la clínica de la disfagia de los pacientes con disfagia neurógena (20). El tratamiento de los pacientes con alteraciones de la apertura del EES como consecuencia de déficits propulsivos debe dirigirse básicamente al incremento en la fuerza de la propulsión del bolo y a la rehabilitación de los mecanismos extrínsecos de apertura del EES, especialmente la acción de la musculatura hioidea (20).

5. Maniobras deglutorias específicas. Se trata de maniobras que el paciente debe ser capaz de aprender y realizar de forma automatizada. Cada maniobra está específica- 
mente dirigida a compensar alteraciones biomecánicas específicas $(12,21)$ :

-Deglución supraglótica (super/supraglótica): su objetivo es cerrar las cuerdas vocales antes y durante la deglución para proteger la vía aérea de aspiración. Es útil en pacientes con penetraciones o aspiraciones durante la fase faríngea o lentitud en el patrón motor deglutorio faríngeo.

-Deglución de esfuerzo o forzada: su objetivo es aumentar el movimiento posterior de la base de la lengua durante la deglución para mejorar la propulsión del bolo. Es útil en pacientes con baja propulsión del bolo.

-Doble deglución: su objetivo es minimizar el residuo postdeglutorio antes de realizar una nueva inspiración. Útil en pacientes con residuo postdeglutorio.

- Maniobra de Mendelsohn: permite incrementar la extensión y la duración de la elevación laríngea, y en consecuencia la duración y amplitud de la obertura del EES.

6. Tratamiento quirúrgico/farmacológico del EES. La identificación del patrón obstructivo a nivel del EES permite el tratamiento de los pacientes mediante la sección quirúrgica del cricofaríngeo (17) o la inyección de toxina botulínica (19).

La VFS va a ayudarnos a seleccionar el tratamiento en función de la severidad de las alteraciones de eficacia y seguridad de cada paciente: a) los pacientes con alteraciones discretas de la eficacia y una correcta seguridad van a poder seguir una dieta libre supervisada por su familia; b) en los pacientes con alteraciones moderadas vamos a introducir cambios dietéticos destinados a disminuir el volumen e incrementos en la viscosidad del bolo alimentario; c) los pacientes con alteraciones severas van a requerir además estrategias basadas en el aumento de la viscosidad y la introducción de técnicas del tipo postural, maniobras activas e incremento sensorial oral; y d) existe un grupo de pacientes con alteraciones tan severas que no es posible tratarlas a pesar de la aplicación de las técnicas de rehabilitación, en estos pacientes la VFS va a permitir demostrar objetivamente que la vía oral no es posible y que es necesario la colocación de una gastrostomía endoscópica percutánea (27). Aunque no existen criterios absolutos, la tendencia de diversos grupos es indicar la gastrostomía en: a) pacientes con alteraciones severas de la eficacia de las fases oral o faríngea y malnutrición; b) pacientes con alteraciones de la seguridad de la fase faríngea sin respuesta al tratamiento rehabilitador; y c) en pacientes con importantes aspiraciones silentes, especialmente en enfermedades neurodegenerativas. En la mayoría de pacientes que requieren una gastrostomía es posible mantener una pequeña proporción de alimentación por la vía oral en condiciones de seguridad.

\section{CONCLUSIÓN}

La actitud a seguir y la relevancia clínica de la disfagia orofaríngea pueden resumirse en cuatro puntos:

1. La disfagia orofaríngea es un síntoma grave, con complicaciones nutricionales y respiratorias que pueden causar la muerte del paciente.

2. Es un síntoma clínicamente poco valorado y poco estudiado a pesar de que existen métodos específicos para su diagnóstico, como la la videofluoroscopia y la manometría faringoesofágica. La figura 1 resume el algoritmo diagnóstico para los pacientes con disfagia orofaríngea.

3. Existen estrategias terapéuticas para los pacientes con disfagia orofaríngea que incluyen cambios en el volumen y viscosidad del bolo, cambios posturales, praxias, maniobras activas, procedimientos de rehabilitación y técnicas de incremento sensorial que han demostrado su eficacia y evitan las complicaciones. Estas técnicas fracasan para tratar algunos pacientes en los que es necesario indicar una gastrostomía para evitar complicaciones respiratorias y nutricionales.

4. El diagnóstico y el tratamiento de los pacientes con disfagia orofaríngea dependen del trabajo en equipo de un grupo multidisciplinar de profesionales formado por médicos, enfermeras, logopedas, dietistas, cuidadores y la propia familia del paciente.

\section{AGRADECIMIENTOS}

Institut Guttmann: Dra. M. Bernabeu, Dra. S. Ramón, Dr. Orient (Unidad de Daño Cerebral), Sra. M. Martinell (Logopeda), Sr. P. Corpas (Radiodiagnóstico).

Hospital de Mataró. Dra. P. Fossas, Dr. Palomeras (Neurología), Dr. M. Cabré (Geriatría), Dra. M. Girvent (Cirugía, estudios nutricionales), Sra. M. Arús (Dietista), Sra. R. Monteis (Enfermería Geriatría), Sra. E. Palomeras.

Fundació de Gastroenterlogía Dr. F. Vilardell. Sr. A. Blanco (Ing. Telecomunicaciones), Sr. R. Farré, Sra Emma Martínez (estudios de viscosidad in vitro).

Hospital de Sant Pau: Dr. J. Pradas, Dr. Rojas (S. Neurología), Dra. R. Güell, Dr. P. Antón (S. Neumología), Sra. M. Casanovas (Escola Patología Lenguaje).

Fundació Dr. Vilardell. Sra. G. Foyo.

Ensayos clínicos desarrollados con el soporte de FIS 98/0794, Novartis Consumer Health S.A. (FCG/NHC-1), Fundació de Gastroenterología Dr. F. Vilardell, y Filial del Maresme de la Academia de Ciencies Mediques de Catalunya i Balears. 